DOI 10.15826/qr.2018.1.282

УДК 94(4-011)"17"+913(470+571)+929Петр $(470)^{\star} \mathrm{I}$

\title{
PETER THE GREAT'S INTERMEZZO \\ WITH G. W. LEIBNIZ AND G. DELISLE: \\ THE DEVELOPMENT OF GEOGRAPHICAL KNOWLEDGE IN RUSSIA*
}

\author{
Kristina Kuentzel-Witt \\ University of Hamburg, \\ Hamburg, Germany
}

\begin{abstract}
During his second trip through Western Europe, Russian Tsar Peter the Great (1672-1725) met the German philosopher Gottfried Wilhelm Leibniz (1646-1716) shortly before the death of the latter in 1716 . Peter was fascinated by Leibniz's ideas and started bringing a new system of education and academic life to Russia. Leibniz was deeply interested in the issue of a land connection between Asia and America, and discussed it with Peter. After meeting the famous French geographer Guillaume Delisle (1675-1726) in Paris in the same year , the tsar began thinking about the usefulness of mapping his country. His encounters with the German and French scientists inspired Peter the Great to found the Academy of Sciences in St Petersburg and introduce astronomy and geography as scientific disciplines. After he returned to his newly founded capital St Petersburg, the tsar started organising large-scale expeditions to investigate and map his empire, including Siberia and Kamchatka during the First and Second Kamchatka Expeditions.
\end{abstract}

Keywords: Peter I; G. W. Leibniz; development of geography in Russia; $18^{\text {th }}$ century.

Во время своей второй поездки по Западной Европе император Петр Великий (1672-1725) встречался с немецким философом Готфридом Вильгельмом Лейбницем (1646-1716) незадолго до смерти последнего в 1716 г. Петра I вдохновили идеи Лейбница, что способствовало его желанию утвердить новую систему образования и науки в России. Лейбница интересовало установление сухопутного сообщения между Азией и Америкой, которое он обсуждал с Петром I. После встречи с Гийомом Делилем (1675-1726), которая состоялась в том же году в Париже, царь стал размышлять о создании подробной карты своей страны. Его встречи с немецким и французским учеными вдохновили Петра на учреждение Академии наук в Санкт-

* Citation: Kuentzel-Witt, K. (2018). Peter the Great's Intermezzo with G. W. Leibniz and G. Delisle: the Development of Geographical Knowledge in Russia. In Quaestio Rossica, Vol. 6, № 1, p. 63-78. DOI 10.15826/qr.2018.1.282.

Цитирование: Kuentzel-Witt K. Peter the Great's Intermezzo with G. W. Leibniz and G. Delisle: the Development of Geographical Knowledge in Russia // Quaestio Rossica. Vol. 6. 2018. № 1. P. 63-78. DOI 10.15826/qr.2018.1.282.

(C) Kuentzel-Witt K., 2018

Quaestio Rossica • Vol. 6•2018 • № 1, p. 63-78 
Петербурге и придание статуса научных дисциплин в России астрономии и географии. По возращении в свою новую столицу Санкт-Петербург царь организовал несколько масштабных экспедиций, в том числе Первую и Вторую Камчатские экспедиции, целью которых было подробное изучение и картографирование всей империи, включая Сибирь и Камчатку.

Ключевые слова: Петр I; Г. В. Лейбниц; развитие географии в России; XVIII век.

\section{Leibniz and Peter the Great}

Gottfried Wilhelm Leibniz (1646-1716) was one of the most important German scientists at the end of the $17^{\text {th }}$ century: he was truly a man of the early German 'enlightenment', and a universal scientist as well [Schippan, 2012]. As was typical for the time, he was not only a specialist in the natural sciences, but also in social and human disciplines [Hirsch; Poser, 2016]. He left such a voluminous oeuvre that the publication of his writings is still going on in Germany, despite having started in 1923 [Leibniz, 1923].

Leibniz was very curious about different countries and cultures: initially, he was particularly interested in Chinese history and culture. In 1689, he stayed for some time in Rome and met there the Jesuit pater Grimaldi, previously a missionary in Beijing. Leibniz was deeply influenced by this contact and started an intensive correspondence with Grimaldi and other Jesuits about China. Much of this correspondence is in French: it was published recently in a German-French edition [Leibniz, 2006]. Leibniz's interests were not only scientific: in his thinking, a strong religious impetus is always noticeable. He understood quite well that the Jesuits brought not only Christian belief to China, but also Western civilization and that they were welcomed in the Chinese capital much more as mathematicians than as missionaries [Keller, S. 394].

In 1697, Leibniz published his famous book about China. In the Novissima Sinica, the reader could find the latest news about China's history and politics. However, this year saw a shift in his interests [Leibniz, 1697; Das Neueste über China] because in 1697-1698 Peter I visited Western Europe for the first time, rousing the attention of the German philosopher [Luckscheiter, S. 298].

As Leibniz searched for more and more information about Asia, Russia, as the state between Europe and Asia, had already entered his field of interests, but his attention increased immediately with the arrival of the young tsar in Western Europe [Keller, S. 398]. Without a doubt, in Leibniz's thinking Western Europe was the leading centre of civilization in the world: today we would characterise it as being truly 'euro-centric' [Nitschke, S. 93]. The enemy here was the Islamic Ottoman Empire. Leibniz had not forgotten that the Ottoman army had been in front of the city walls of Vienna in 1683, so he dreamed of a stronger connection between the different Christian countries to protect Europe against Constantinople [Ibid.].

Leibniz saw Russia, an Orthodox but Christian state, as a natural ally of Western European countries that could bring Christianity to Asia [Poser, 2013]. It is worth noting that Leibniz, a Protestant, grossly underestimat- 
ed the importance of the Orthodox Church in Russia. This is why he was able to think of Russia as a state where no deeply rooted religion and no scientific life existed: thus, he spoke of a 'tabula rasa' when he characterized Russia [Копанев]. This he meant in a positive sense, regarding Russia as a country were new things could develop without the same mistakes that had been made in Europe. In a letter from May 1697, he wrote to an unknown acquaintance at the court of Wolfenbuettel:

Je m’en vay luy écrire, que puisque le Czar veut débarbariser son pays, il y trouvera Tabulam Rasam comme une nouvelle terre, quon veut défricher, les Moscovites nềtant pas encore prévenus en matière de science... [Guerrier, p. 9] ${ }^{1}$.

This concept of the Russian 'tabula rasa', a long-lasting thesis he continued to write about until 1708, became famous [Копанев, p. 38]. Of course, it is much criticized today, although his contemporaries mostly accepted it because knowledge about Russia was very limited at that time [Groh, S. 43]. In her recently published article, Christine Roll analyses this reductionist vision of Leibniz's image of Russia very critically. In her view, Leibniz's understanding of Russia was much more complex: it is just that he deliberately used a few attention-grabbing slogans to get more attention for his thesis and for Russia from the Western European public [Roll].

While Leibniz was initially only interested in Russia as a 'mediator' between Europe and China, this changed when Peter I (1672-1725) came to Europe on his first trip [Bayuk, Fedorova, S. 213]. The 52-year-old German Protestant scientist was fascinated by the idea of a young tsar travelling incognito through half of Europe. Leibniz tried hard to establish contact with Peter, but could only do so through François Lefort, the tsar's influential old friend [Schippan, 2013, S. 138]. A fixed point in Leibniz's ideas was the question of whether there was a land bridge between Asia and America: as early as 1697 , he sent a detailed plan about his ideas to Lefort in order to have them presented to the tsar. Leibniz wrote:

Pour faire les cartes, il faudroit envoyer des ingénieurs, observer les hauteurs, longitudes et variations de l'aimant, reconnoistre les côtes sur tout dans le Nordest autant qu'il se peut, pour apprendre si l'Asie est jointe à l'Amérique, ou si on peut passer entre eux [Guerrier, part 2, no. 14, p. 19]².

So, his plans involved much more than the search for a land connection between the two continents: he wanted to map the whole area. Meanwhile, Leibniz started a correspondence with Nicolaas Witsen (1641-1717), the

1 "Let me write to you that the Tsar will 'debarbarize' his country, and he will find a 'tabula rasa' like a new country, which he will cultivate: the Moscovites are no longer prejudiced against the sciences at all..." (Here and then translation of the author).

2 "To make the maps, he will need to send engineers and make observations of the latitudes, longitudes and variations of the magnet in order to investigate the entire coastline of the northeast, especially [if one wants] to know if Asia is connected to America and if you can pass between them." 
mayor of Amsterdam and a good friend of Peter I, who was famous for his map of Asia and later for his book Noord en Oost Tartarye [Witsen; Keuning]. Both scientists informed each other about the Asian part of Russia.

Shortly after the Great Northern War with Sweden started, Leibniz remained in contact with the Russian government. Although the young Swedish King Charles XII was almost seen as the leader of Protestant Europe and was very popular at the beginning of the war (certainly Leibniz had some sympathies for him), the philosopher still tried to get more information about Russia and establish contact with the tsar [Schippan, 2013, S. 142].

At first, the Russian side did not react to Leibniz's proposals. During the early stage of the Great Northern War, Peter I had no time or energy left over for Leibniz's educational projects, but the political situation changed completely in 1709 after the Battle at Poltava. Finally, the German scientist and Peter I met personally in Torgau 1711 [Ibid., S. 149]. A document about their meeting entitled Soderzhanie razgovora Petra Velikogo s Leibnitsem $v$ Torgau was found in the materials of the reformer Michail Speransky at the Russian National Library: it contains severe criticism of Russian living conditions. This document is very suspicious because Speransky lived at the beginning of the $19^{\text {th }}$ century: this begs the question of why such a document about Leibniz and Peter I is among his papers. The authenticity of this paper has always been questioned, and experts are quite sure that it is a forgery [Мезин, с. 118; Копанев, p. 37; Schippan, 2013, S. 152].

One year later, Peter I and Leibniz stayed together for several weeks in Karlsbad, where Peter tried to restore his health [Keller, p. 406]. Meanwhile, Leibniz was officially named a consultant of the Russian government and began to work on several memoranda for bringing scientific life in Russia. His most important plans he presented to Peter I personally in June 1716 in Bad Pyrmont shortly before his death [Piel, Luber, S. 93]. These included the establishment of Western European sciences in Russia via an academy of science. In the plans of the German philosopher, this academy should not only be for scientists, but should also educate the broader public. In another memorandum, Leibniz proposed establishing the so-called 'Kollegien' which reorganized the Russian state [Keller, S. 404; Schippan, 2013, S. 149]. Finally, he stressed again that it would be very valuable to know if there was a land connection between Asia and America. In pursuit of this goal, it would be beneficial to develop geographical knowledge in Russia [Maier, S. 21-23].

Leibniz wrote:

Es kann auch durch ordre S. Cz. Mt. aussgefunden warden ob Asien gegen Norden zu umbschiffen, oder ob das äusserste Eisscap an Amerika hange, welches die Engländer und Holländer durch gefährliche Schiffahrt vergebens gesuchet [Guerrier, part 2, doc. 240, p. 360] $]^{3}$.

3 "By the order of His Majesty it could be known if there is an opportunity to sail around the northern edge of Asia or if this edge belongs to America, which British and Dutch sailors have already tried to find out." 
Leibniz penned a remarkable letter to his Swiss colleague, the natural scientist and geographer Louis Bourguet. Bourguet held the view that a land connection between Asia and America must exist because he believed in the theory of a worldwide great flood. The letter is from 2 July 1716, so Leibniz wrote it shortly after his meeting with Peter I:

Je ne saurois assez admirer la vivacité et le jugement de ce grand Prince. Il fait venir des habiles gens de touts côtes, et quand il leur parle, ils en sont tout étonnés, tant il leur parle à propos. Il s'informe de tous les arts mécaniques; mais sa grande curiosité est pour tout ce qui a du rapport à la navigation; et par consequent il aime aussi l'Astronomie et la Géographie. J'espère que nous apprendrons par son moyen, si l'Asie est attaché à l'Amérique [Guerrier, part 2, doc. 241, p. 360$]^{4}$.

In the same year, Bourguet wrote a letter to Guillaume Delisle to discuss the question of a land connection between both continents. He was so obsessed with this theme that he wrote in 1737, 21 years later, another letter to Guillaume's younger brother, Joseph-Nicolas Delisle, on this topic [Chabin, 1983, p. 174]. Afterwards, Bourguet published an article about his inquiries in the Mercure Suisse, which roused the attention of the Swiss geographer Samuel Engel: he later started a controversy about the geographical data on Siberia because he distrusted Russian observations and publications about the existence of a passage along the Siberian coast to America and the size of Siberia [Kuentzel-Witt, S. 162].

While Leibniz was fascinated by the tsar, Peter, for his part, was impressed by Leibniz and his ideas. After he returned to Russia, he began to install a new system of education and academic life in Russia, as is well known [Невская, с. 15; Schippan, 2013, S. 151]. However, Leibniz was not his only source of inspiration: Peter's visit to Paris the following year and his encounter with French scientists at the Sorbonne was another influential encounter with scientific life in Western Europe that persuaded the Russian tsar to establish academic institutions in Russia.

\section{Peter the Great and Guillaume Delisle}

For the development of geography in Russia, Guillaume Delisle (or de l'Isle) (1675-1726) was especially important because Peter the Great met the famous French geographer during his stay in Paris in 1717 at a special session of the Academy in Paris, at which time they discussed Delisle's maps of Russia and Asia from 1706 [Chabin, 1985, p. 569]. Delisle soon became the first royal geographer and taught the dauphin geography.

4 "I can't admire enough the vivacity and the power of judgement of the grand prince. He let all the knowledgeable people of the region come to him, and they were quite astonished how he spoke with them. He was informed about all the mechanical sciences, but especially navigation rouses his curiosity and consequently astronomy and geography, too. With his help, I hope that we will find out if Asia is connected to America." 
Guillaume Delisle belonged to a very well recommended family of scientists in France. His father was the historian and geographer Claude Delisle (1644-1720), who himself was very interested in Russia and had established relatively close contact with Petr Postnikov, who stayed in Paris as an ambassador. Marie-Anne Chabin wrote about this in her dissertation Les Français et la Russie dans la première moitié du XVIIIe siècle: La famille Delisle et les milieux savants, which was never published, a rather regrettable circumstance because we possess few published materials about the Delisle family [Chabin, 1983; Isnard; Les Français en Russie].

Guillaume, without question the most able of the surviving four sons of Claude Delisle, was educated by the famous geographer Jean-Dominique Cassini (1625-1712) (later his younger brother Joseph-Nicolas (1688-1768) was also a student of Cassini) [Chabin, 1985, p. 565]. During the times of Nicolas Sanson and Cassini, France was the centre of cartography and the map trade in Europe.

Guillaume Delisle was very productive: he mapped the whole world, despite never leaving Paris for other countries. He developed a new style of geography called 'positive geography'. Mary Sponberg Pedley has characterized this new method in the following terms: "Guillaume Delisle (1675-1726), who was himself a student of Jean Dominique Cassini, mastered the techniques of 'positive geography', extending Sanson's approach by gathering and analysing all information - cartographic and literary - about a region. Working together with his father, Guillaume Delisle spectacularly changed the image of the world for the French public through his maps: The Mediterranean shrank by 300 leagues in breadth; the Atlantic and Indian Oceans were equally reduced and the Pacific greatly enlarged. In North America the familiar shape of California as an island now was transformed into a peninsula. Delisle's maps marked what Vaugondy and many after him called 'the reform of cartography"' [Pedley Sponberg, p. 19].

Delisle is still very well known for his maps of America [Dawson, p. 65], but his map of the European part of Russia and the Carte de Tartarie, both from 1706, were of particular interest to the tsar. Delisle's map of European Russia, the so-called La carte de Moscovie, had been a great success, which may be why Peter I wanted to meet Delisle personally [Chabin, 1983, p. 237]. The discussion between tsar and geographer seems to have been lively. Giulia Cecere has written that Peter corrected the latitude of St Petersburg on Delisle's map of Russia [Cecere, p. 130]. The tsar also made some corrections and annotations to the map of Asia and ordered a map of the Caspian Sea from Delisle. The Caspian Sea was a special project for Peter I. He had been interested in the area since 1699 and its mapping continued until his death in 1725 [Shaw, p. 164]. The two men also debated the frontiers of Russia in Asia and the Pacific coastline, afterwards promising to keep in contact and exchange information [Chabin, 1985, p. 568].

In the scientific journal Acta Eruditorum, a report of Peter's visit in Paris was published, thus demonstrating how important this was for the scientific community. It is especially mentioned that the tsar corrected Delisle's maps [Acta Eruditorum, p. 507]. 


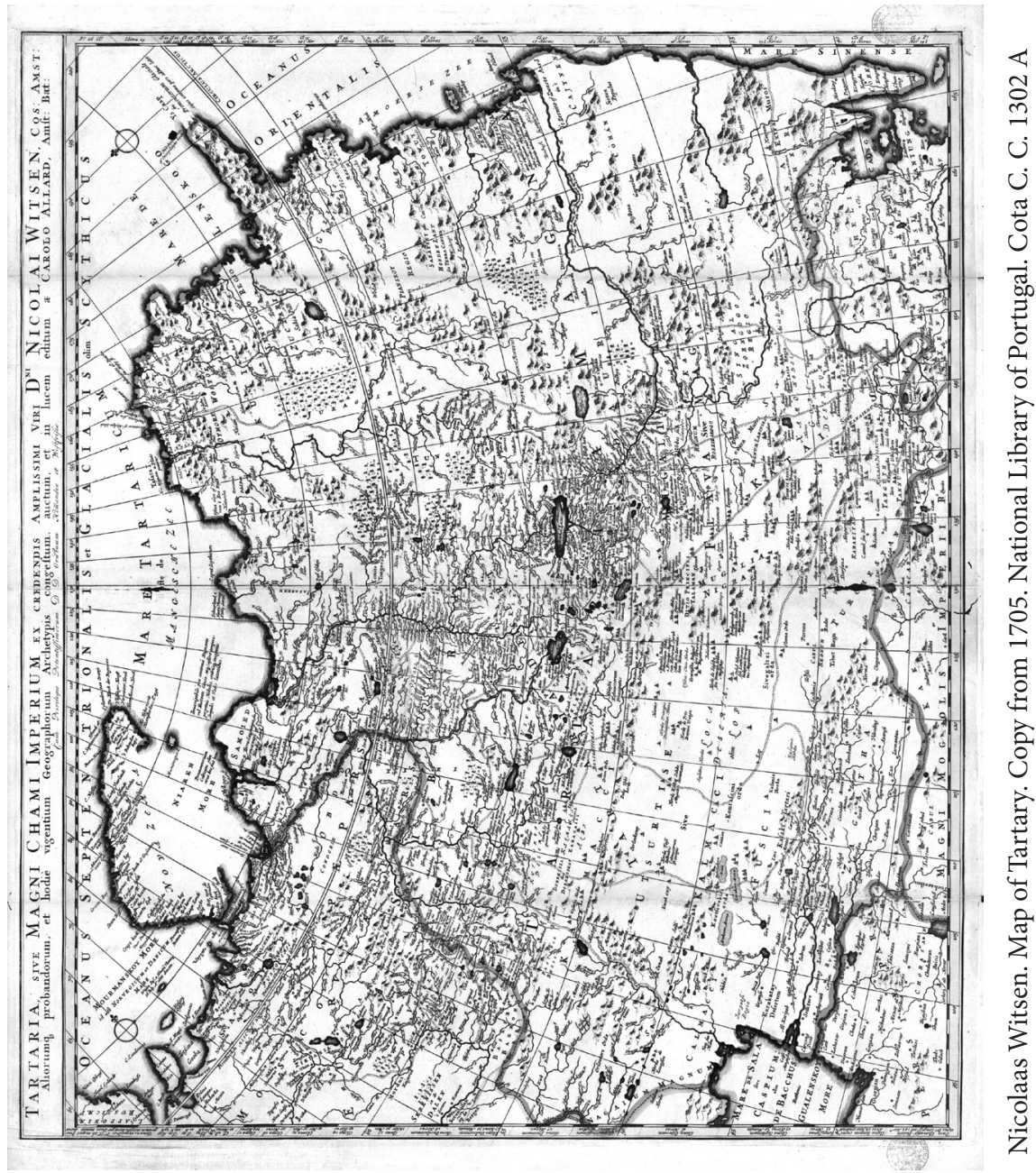


Like Leibniz, Delisle was influenced by the older map made by Nicolaas Witsen, who spent several months in 1665 in Moscow accompanying Jacob Borel, the ambassador of the Netherlands in Russia. Witsen was not allowed to leave the city, but he met Tatars, Samoyeds and other Siberian peoples: after his trip, he collected other materials from Asia, mostly from Jesuits [Keuning, S. 95]. He published his famous map in 1687.

On Witsen's map, there is no Kamchatka Peninsula: nor is it present on Guillaume Delisle's map of "Tartarie". The coastline on the Asian side was left open, a sign of just how unclear the geography of the northern part of Asia was in 1706. The whole Russian Artic coastline is almost completely wrong: even the stretch from Novaja Zemlja to the Kara Sea is only a sketch because geographers were still uncertain if it was an island or a peninsula. The most remarkable thing is that the whole Asian part of the map looks as if it has been contracted and crowded together, while Eastern Siberia appears much larger.

These maps Peter the Great corrected, but it is unlikely that he was wellenough informed to correct the general error about the length of the Asian continent (at least, such a criticism from his side is absent in the reports). However, he understood quite well how rudimentary Western European and Russian knowledge about his empire, especially Siberia, was.

So, after returning to Russia, Peter sent two geodesists, Ivan M. Evreinov and Fedor F. Luzhin, to Kamchatka to map the peninsula and the nearest Kuril Islands in 1719 [Dahlmann, S. 112]. Marie-Anne Chabin stresses that even the names 'Kamchatka' and 'Siberia' were only established in France after Peter's visit: beforehand, 'la Sibérie' was called 'Tartarie' or 'La Tartarie septentrionale', while Kamchatka was either entirely unknown or referred to as 'Kamzat' [Chabin, 1985, p. 239].

On Delisle's map of this region, an island called Terre d'Eso ou d'Yeço is marked to the east of the Amur basin. In older maps by Nicolas Sanson, for example, Yeço or Jeso looked as if it was as large as a whole continent, so Delisle minimized it [Carte des Tartarie]. It took several years for Jeso to disappear from French maps because in reality it was the Japanese island of Hokkaido.

Guillaume Delisle's map of Asia, published in 1722 after the meeting with Peter I, shows some important differences in comparison with the earlier map. The Asian continent looks much larger, Kamchatka as a peninsula is visible, and the Kuril Islands and Sakhalin Island have been sketched in. The form of Novaja Zemlja is more realistic, but the coastline of the Kara Sea is only outlined. The geography of Cape Dezhnev remained entirely unknown: only the small part above the eastern edge is illustrated. When the maps of 1706 and 1722 are compared, the progress is undeniable (Il. 2). However, despite Delisle's map of Asia, a heavy dispute between French geographers about the correct placement of Kamchatka broke out some years later. It is quite astonishing that Guillaume Delisle's map did not play an important role in this debate [Verdier, p. 119]. 


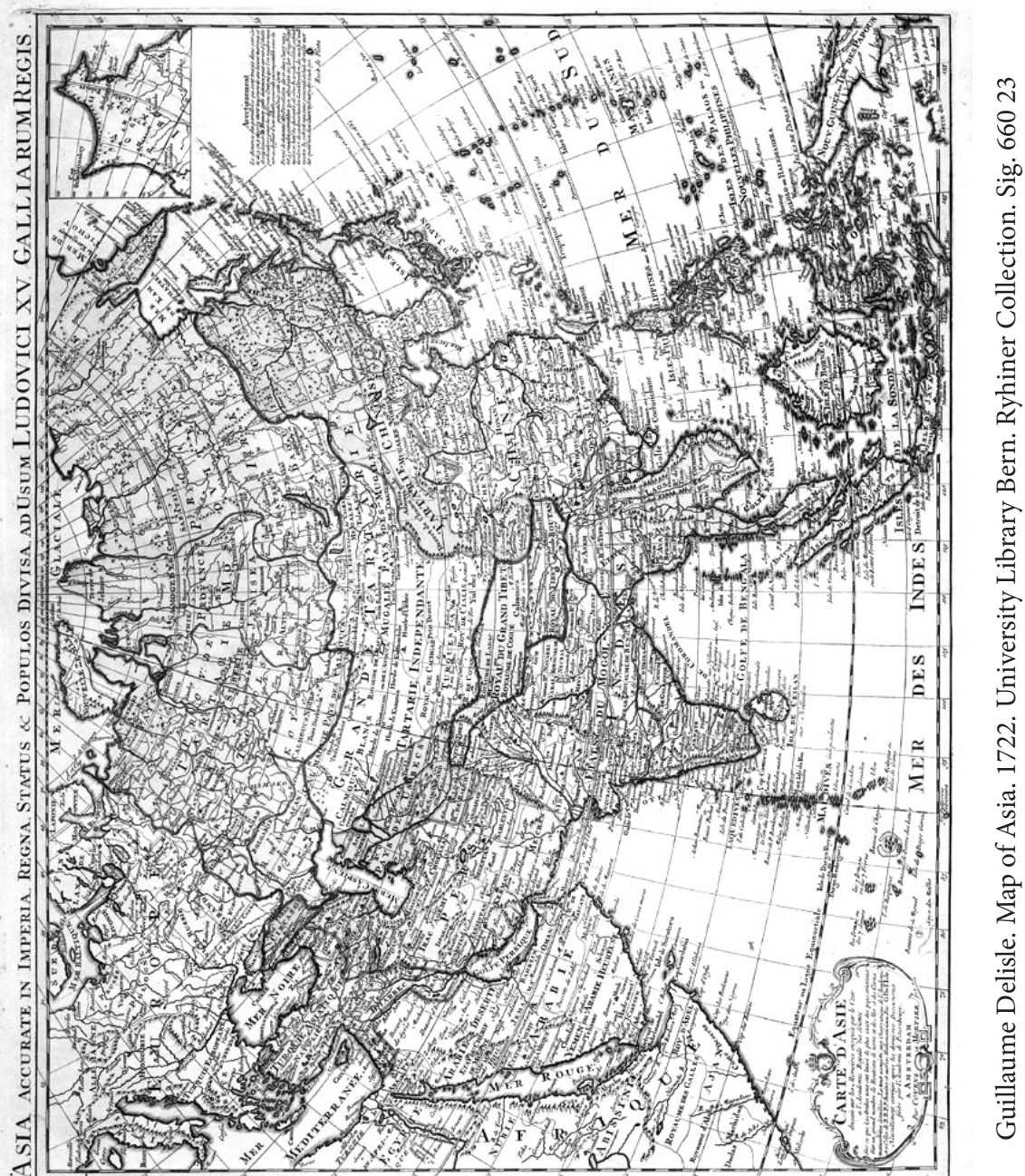


In conclusion, it must be noted that the encounters with the German and French scientists inspired Peter the Great to found the Academy of Sciences in St Petersburg and establish astronomy and geography as academic disciplines in Russia. The tsar had already founded in 1701 a school of mathematics and navigation led by Farquharson, where many geodesists were educated, but after Leibniz's memoranda and his contact with the French Academy of Science and the Sorbonne, Peter became even more interested in founding scientific institutions. A lot of the schools he opened concentrated on practical knowledge, but Peter's ideas became more 'academic' after his last trip to Europe. Interestingly, before the time of Peter I the word 'geography' was unknown in Russia: the older Russian term was 'zemleopisanie', but during his reign 'geografija' was introduced. This change in terminology helps to explain how different the status and understanding of 'geography' became in Russia during Peter's rule [Shaw, p. 173].

After the tsar returned to his new capital of St Petersburg, he started to organise several expeditions to investigate and map Siberia and Kamchatka. Shortly before his death, he established the First Kamchatka Expedition, which lasted from 1725 to 1730 [Dahlmann, S. 115-118]. In 1721, Peter the Great invited Guillaume Delisle via Schumacher to come to Russia and work there, but the geographer declined his offer: his younger brother, Joseph-Nicolas Delisle (1688-1768), went instead [Chabin, 1985, p. 568]. In 1725, Joseph-Nicolas left Paris together with his other brother Louis Delisle de la Croyère (1687?-1741) and opened an observatory in St Petersburg.

Meanwhile, Guillaume Delisle died unexpectedly in Paris in 1726: Philippe Buache, his son in law, continued his business. Joseph-Nicolas Delisle became one of the first professors at the Academy of Sciences and published the first Russian atlas together with Ivan Kirilov in 1745, although it is well known that their cooperation was not without its difficulties. So, the Delisles remained important for the development of geography in Russia: in 1735, for example, Joseph-Nicolas was installed at the Academy's department of geography.

Without question, Guillaume Delisle's influence on his younger brother Joseph-Nicolas was great. The latter drew a map of the North Pacific based on the studies of his famous brother: it was this map that Bering and Chirikov took with them on the Second Kamchatka Expedition, accompanied by Louis Delisle de la Croyère as an astronomer. Joseph-Nicolas Delisle's map shows three large islands ("Jeso", "Compagnieland" (or Staten Island) and "da Gama-Land") which did not exist in this form [Андреев; Breitfuss; Lagarde]. Bering wanted to reach them and so set his course too far to the south: instead of 1,400 sea miles, the distance to the passage was actually 3,500. This error made him lose too much time [Breitfuss, p. 92].

Because of this map and his behaviour after he left St Petersburg, Joseph-Nicolas Delisle is still one of the most controversial scientists of the $18^{\text {th }}$ century. His report and letters from his trip to Berezov in 1740 were 
published in Russian for the first time in 2008 [Материалы экспедиции Ж.-Н. Делиля, с. 26]. He has recently been the subject of a heated debate between French and Russian colleagues, with the latter accusing Delisle of taking many Russian maps illegally to France [Гузарова; Гузевич Д., Гузевич И.]. This debate shows clearly how differently the historical heritage of this period is perceived in Russia and Western Europe: evidently, there are lots of points still worthy of discussion. From my point of view, the influence of Joseph-Nicolas Delisle for the development of geographical science in Russia should not be forgotten, regardless of the ongoing discussion over whether he was a spy. Here I have concentrated on the encounters of Peter the Great with Leibniz and Guillaume Delisle and how important they were for the development of geographical knowledge in Russia because, in Germany at least, the influence of Delisle is underestimated.

\section{Список литературы}

Андреев А. И. Труды Г. Ф. Миллера о Сибири // Миллер Г. Ф. История Сибири : в 3 т. 3-е изд. М. : Вост. лит., 2005. Т. 1. С. 66-149.

Гузарова E. В. К вопросу об этической стороне «альтернативного» взгляда на деятельность астронома Делиля в России // Труды Государственного Эрмитажа. Т. 70. Петровское время в лицах - 2013 : K 400-летию дома Романовых (1613-2013) : материалы науч. конф. СПб. : Изд-во Гос. Эрмитажа, 2013. С. 121-136.

Гузевич Д., Гузевич И. «В начале был Делиль», или Гипотеза о причинах расформирования одной французской коллекции // Труды Государственного Эрмитажа. Т. 73. Петровское время в лицах - 2014 : K 300-летию победы при Гангуте (1714-2014) : материалы науч. конф. СПб. : Изд-во Гос. Эрмитажа, 2014. С. 112-120.

Копанев Н. А. «Tabula rasa» Г. В. Лейбница // Г. В. Лейбниц и Россия : Из истории Петербургской академии наук / под ред. Н. П. Копаневой. СПб. : Европ. дом, 1998. C. $35-40$.

Материалы экспедиции Ж.-Н. Делиля в Березов в 1740 г. : Дневник Т. Кенигсфельда и переписка Ж.-Н. Делиля / вступ. ст. и сост. Н. В. Кирющенко, П. А. Кротова ; отв. ред. С. А. Козлов. СПб. : Ист. иллюстрация, 2008. 544 с.

Мезин С. А. Петр I, Лейбниц и Сперанский // Российская история. 2011. № 1. C. $115-120$.

Невская Н. И. Г. В. Лейбниц и Петербургская академия наук в XVIII в. // Г. В. Лейбниц и Россия : Из истории Петербургской академии наук / под ред. Н. П. Копаневой. СПб. : Европ. дом, 1998. С. 15-27.

Bayuk D. A., Fedorova O. B. Leibniz in Russian // Komma und Kathedrale : Traditon, Bedeutung und Herausforderung der Leibniz-Edition. Internationale Konferenz in Hannover 2011 / Hrsg. von W. Li. Berlin : Akademie Verlag, 2012. S. 213-224.

Breitfuss L. Early Maps of North-Eastern Asia and of the Lands around the North Pacific : Controversy between G. F. Mueller and N. Delisle // Imago Mundi. 1939. Vol. 3. P. 87-99.

Carte des Tartarie : Dressée sur le Relations de plusieurs Voyageurs de differents Nations et sur quelque Observations qui ont été faites dans ee pais La Par Guillaume De l'Isle de l'Academie Royale des Sciences. A Paris avec Privilege, 1706 // Bibliothèque Nationale de France (Site Richelieu, collection of the maps). Sig. GeAF. Portefeuille 3. No. 23.

Cecere G. Wo Europa endet : Die Grenze zwischen Europa und Asien im 18. Jahrhundert // Kartenwelten. Der Raum und seine Repräsentation in der Neuzeit / Hrsg. von Ch. Dipper, U. Schneider. Darmstadt : Primus, 2006. S. 127-145.

Chabin M.-A. La curiosité des savants français pour la Russie dans la première moitié du XVIIIe siècle // Revue des Études Slaves. 1985. T. 57. Fasc. 4. P. 565-589. 
Chabin M.-A. Les Français et la Russie dans la première moitié du XVIIIe siècle. La famille Delisle et les milieux savants : Mémoire ou thèse de l'École nationale des chartes. Paris : [S. n.], 1983. 345 p.

Dahlmann D. Sibirien. Vom 16. Jahrhundert bis zur Gegenwart. Paderborn : Ferdinand Schöningh, 2009. $435 \mathrm{~S}$.

Das Neueste über China. G. W. Leibnizens Novissima Sinica von 1697 : Intern. Symp., Berlin, 4. bis 7 Oktober 1997 / Hrsg. W. Li, H. Poser. Stuttgart : Franz Steiner, 2000. 390 S. (Studia Leibnitiana. Supplementa. Vol. 33).

Dawson N.-M. L'Atelier Delise, L'Amerique du Nord sur la table à dessin. Avec la collaboration de Charles Vincent. Quebec : Sillery, 2000. 306 p.

Groh D. Russland im Blick Europas. 300 Jahre historische Perspektiven. Frankfurt a/M : Suhrkamp, 1988. 439 S.

Guerrier W. Leibniz in seinen Beziehungen zu Rußland und Peter dem Großen : Eine geschichtliche Darstellung dieses Verhältnisses nebst den darauf bezüglichen Briefen und Denkschriften. St Petersburg; Leipzig : Kaiserliche Akademie der Wissenschaften, 1873. XVIII $+372 \mathrm{~S}$.

Hirsch E. Ch. Der berühmte Herr Leibniz : Eine Biographie. München : C. H. Beck, 2000. $640 \mathrm{~S}$.

Historia Academiae Regiae Scientiarum Anni 1720 // Acta Eruditorum. 1724. S. 498-508.

Isnard A. Joseph-Nicolas Delisle, sa biographie et sa collection de cartes géographiques à la bibliothèque nationale // Bulletin de la section de Géographie. T. 30. Paris : Imprimerie Nationale, 1915. P. 34-164.

Keller M. Wegbereiter der Aufklärung : Gottfried Wilhelm Leibniz' Wirken für Peter den Großen und sein Reich // West-östliche Spiegelungen Reihe A. Vol. 1. Russen und Rußland aus deutscher Sicht, 9. - 17. Jahrhundert / Hrsg. von L. Kopelew. München : Wilhelm Fink, 1985. S. 391-413.

Keuning J. Nicolaas Witsen as a Cartographer // Imago Mundi. 1954. Vol. 11. P. 95-110.

Küntzel-Witt K. Wie groß ist Sibirien? Die russischen Entdeckungen im Pazifik und die Kontroverse zwischen Joseph Nicolas Delisle, Samuel Engel und Gerhard Friedrich Müller im 18. Jahrhundert // Osteuropa kartiert - Mapping Eastern Europe. Unter Mitarbeit von Mira Jovanović / Hrsg. von J. Happel, Ch. von Werdt. Berlin ; Zürich : Lit, 2010. S. $155-172$.

Lagarde L. Le Passage du Nord-Ouest et la Mer de l'Ouest dans la Cartographie français du $18^{\mathrm{e}}$ Siècle, Contribution à l'Etude de l'Oeuvre des Delisle et Buache // Imago Mundi. 1989. Vol. 41. P. 19-43.

Leibniz G. W. Der Briefwechsel mit den Jesuiten in China (1689-1714). Französisch/ lateinisch/deutsch / Hrsg. und mit einer Einleitung versehen V. R. Widmaier ; Textherstellung und Übersetzung V. M.-L. Babin. Hamburg : Felix Meiner, 2006. CXXXVII + 894 S. (Ser. Philosophische Bibliothek. Vol. 548).

Leibniz G. W. Novissima Sinica (1697). Das Neueste von China / Hrsg. von H. G. Nesselrath, H. Reinbothe. Köln : Deutsche China-Gesellschaft, 1979. XIII + 159 S.

Leibniz G. W. Sämtliche Schriften und Briefe. Berlin : Deutsche Akademie der Wissenschaften : [S. n.], 1923.

Les Français en Russie au siècle des Lumières : Dictionnaire des Français, Suisses, Wallons et autres francophones en Russie de Pierre le Grand à Paul Ier : en 2 vol. / sous la direction de A. Mezin, V. Rjéoutski. Ferney-Voltaire : Centre Intern. d'Étude du XVIIIe siècle, 2011. $1424 \mathrm{p}$.

Luckscheiter S. Auskünfte für und von Leibniz über Zar Peter I. und die große russische Gesandtschaft (1697-1698) // Komma und Kathedrale : Tradition, Bedeutung und Herausforderung der Leibniz-Edition : Intern. Konf. in Hannover, 2011 / Hrsg. von W. Li. Berlin : Akademie Verlag, 2012. S. 293-300.

Maier L. Das Sibirienbild in den deutschsprachigen Werken Gerhard Friedrich Müllers // Deutsche auf dem Ural und in Sibirien (XVI-XX Jh.) Forschungsbeiträge der wissenschaftlichen Konferenz «Deutschland - Russland: historische Erfahrungen interregionaler 
Zusammenarbeit im XVI.-XX. Jahrhundert» / Hrsg. von N. N. Baranov. Ekaterinburg : Volot, 2001. S. 20-54.

Nitschke P. Die Leibnizsche Vision von Europa // Gottfried W. Leibniz: Die richtige Ordnung des Staates / Hrsg. von P. Nitschke. Baden-Baden : Nomos, 2015. (Staatsverständnisse. Vol. 72). S. 91-111.

Pedley Sponberg M. Bel et Utile : The Work of the Robert De Vaugondy Family of Mapmakers. Exeter : [S. n.], 1992.

Piel G., Luber S. Ein "berühmtes Pyrmonter Brunnenjahr" : Zar Peter I in Pyrmont im Juni 1716 // Zar Peter der Große : Die zweite große Reise nach Westeuropa 1716-1717 / Hrsg. von D. Alfter. Hameln : Niemeyer, 1999. S. 87-96.

Poser H. Leibniz' Novissima Sinica as a Program for the Reunification of the Christian Confessions // Leibniz und die Ökumene / Hrsg. von W. Li, H. Poser, H. Rudolph. Stuttgart : Franz Steiner, 2013. (Studia Leibnitiana. Sonderhefte. Vol. 41). S. 75-86.

Poser H. Leibniz' Philosophie : Über die Einheit von Metaphysik und Wissenschaft / Hrsg. von W. Li. Hamburg : Felix Meiner, 2016. 528 S.

Roll Ch. Barbaren? ,Tabula rasa"? Wie Leibniz sein neues Wissen über Russland auf den Begriff brachte. Eine Studie über die Bedeutung der Vernetzung gelehrter Korrespondenzen für die Ermöglichung aufgeklärter Diskurse // Umwelt und Weltgestaltung : Leibniz' politisches Denken in seiner Zeit / Hrsg. von V. F. Beiderbeck, I. Dingel, W. Li. Göttingen : Vandenhoeck \& Ruprecht, 2015. (Veröffentlichungen des Instituts für Europäische Geschichte Mainz. Beiheft 105). S. 307-358.

Schippan M. Der „Solon Russlands“ und der Zar. Gottfried Wilhelm Leibniz, Peter der Große und die europäischen Wissenschaftsbeziehungen // Gottfried Wilhelm Leibniz (1646-1716) und die gelehrte Welt Europas um 1700 / Hrsg. B. Heinecke, I. Kästner. Aachen : Shaker, 2013. (Europäische Wissenschaftsbeziehungen. Vol. 6). P. 133-154.

Schippan M. Die Aufklärung in Russland im 18. Jahrhundert. Wiesbaden : Harrassowitz, 2012. 493 S. (Wolfenbütteler Forschungen. Vol. 131).

Shaw D. J. B. Geographical Practice and its Significance in Peter the Great's Russia // J. of Historical Geography. 1996. Vol. 22. P. 160-176.

Verdier N. Des Cartes en situation d'intercertitude : La controverse sur le Kamtchatka entre 1737 et 1738 comme révélateur d'une crise de la cartographie française // Век Просвещения / отв. ред. С. Я. Карп ; сост. Г. А. Космолинская. Вып. 5. География эпохи Просвещения: между воображением и реальностью. М. : Наука, 2015. C. $100-120$.

Witsen N. Tartaryen : Behelende Eene Beschryving van verscheidene Tartersche en Nabuurige Gewesten, in de Noorder en Oostelykste Deelen van Azien en Europa... Te Amsterdam 1785; 2. Teil: Noord en Oost Tartarye; Tweede Deel: Behelzende de Landschappen Georgia, Mengrelia, Cirkassia, Crim, Astakkia, Altin, Tingoesia, Siberia, en Samojedia door Nicolaes Witsen. Amsterdam 1785 (3 Ed., the first and shorter ed. is from 1692).

\section{References}

Andreev, A. I. (2005). Trudy G. F. Millera o Sibiri. In Miller G. F. Istoriya Sibiri [History of Siberia. 3 Vols.]. Ed. 3. Moscow, Vostochnaya literatura. Vol. 1, pp. 66-149.

Bayuk, D. A., Fedorova, O. B. (2012). Leibniz in Russian. In Li, W. (Hrsg.). Komma und Kathedrale: Tradition, Bedeutung und Herausforderung der Leibniz-Edition. Internationale Konferenz in Hannover 2011. Berlin, Akademie Verlag, S. 213-224.

Breitfuss, L. (1939). Early Maps of North-Eastern Asia and of the Lands around the North Pacific : Controversy between G. F. Mueller and N. Delisle. In Imago Mundi. Vol. 3, pp. 87-99.

Carte des Tartarie : Dressée sur le Relations de plusieurs Voyageurs de differents Nations et sur quelque Observations qui ont été faites dans ee pais La Par Guillaume De l'Isle de l'Academie Royale des Sciences. A Paris avec Privilege, 1706. In Bibliothèque Nationale de France (Site Richelieu, Collection of the maps). Sig. GeAF. Portefeuille 3. No. 23. 
Cecere, G. (2006). Wo Europa endet : Die Grenze zwischen Europa und Asien im 18. Jahrhundert. In Dipper, Ch., Schneider, U. (Hrsg.). Kartenwelten. Der Raum und seine Repräsentation in der Neuzeit. Darmstadt, Primus, S. 127-145.

Chabin, M.-A. (1983). Les Français et la Russie dans la première moitié du XVIIIe siècle. La famille Delisle et les milieux savants. Mémoire ou thèse de l'École nationale des chartes. Paris, S. n. 345 p.

Chabin, M.-A. (1985). La curiosité des savants français pour la Russie dans la première moitié du XVIIIe siècle. In Revue des Études Slaves. T. 57. Fasc. 4, pp. 565-589.

Dahlmann, D. (2009). Sibirien. Vom 16. Jahrhundert bis zur Gegenwart. Paderborn, Ferdinand Schöningh. $435 \mathrm{~S}$.

Dawson, N.-M. (2000). L'Atelier Delise, L'Amerique du Nord sur la table à dessin. Avec la collaboration de Charles Vincent. Quebec, Sillery. 306 p.

Groh, D. (1988). Russland im Blick Europas. 300 Jahre historische Perspektiven. Frankfurt am Main, Suhrkamp. 439 S.

Guerrier, W. (1873). Leibniz in seinen Beziehungen zu Rußland und Peter dem Großen. Eine geschichtliche Darstellung dieses Verhältnisses nebst den darauf bezüglichen Briefen und Denkschriften. St Petersburg, Leipzig, Kaiserliche Akademie der Wissenschaften. XVIII $+372 \mathrm{~S}$.

Guzarova, E. V. (2013). K voprosu ob eticheskoi storone "al'ternativnogo" vzglyada na deyatel'nost' astronoma Delilya v Rossii [On the Ethical Side of the 'Alternative' View of the Activities of Astronomer Delisle in Russia]. In Trudy Gosudarstvennogo Ermitazha. Vol. 70. Petrovskoe vremya v litsakh - 2013. K 400-letiyu doma Romanovykh (1613-2013). Materialy nauchnoi konferentsii. St Petersburg, Izdatel'stvo Gosudarstvennogo Ermitazha, pp. 121-136.

Guzevich, D., Guzevich, I. (2014). "V nachale byl Delil"”, ili gipoteza o prichinakh rasformirovaniya odnoi frantsuzskoi kollektsii ["In the Beginning There Was Delisle", or a Hypothesis about the Reasons for the Dispersal of the French Collection]. In Trudy Gosudarstvennogo Ermitazha. T. 73. Petrovskoe vremya v litsakh-2014. K 300-letiyu pobedy pri Gangute (1714-2014). Materialy nauchnoi konferentsii, St Petersburg, Izdatel'stvo Gosudarstvennogo Ermitazha, pp. 112-120.

Hirsch, E. Ch. (2000). Der berühmte Herr Leibniz : Eine Biographie. München, C. H. Beck. $640 \mathrm{~S}$.

Historia Academiae Regiae Scientiarum Anni 1720. (1724). In Acta Eruditorum. S. 498-508.

Isnard, A. (1915). Joseph-Nicolas Delisle, sa biographie et sa collection de cartes géographiques à la bibliothèque nationale. In Bulletin de la section de Géographie. T. 30. Paris, Imprimerie Nationale, pp. 34-164.

Keller, M. (1985). Wegbereiter der Aufklärung : Gottfried Wilhelm Leibniz' Wirken für Peter den Großen und sein Reich. In Kopelew, L. (Hrsg.). West-östliche Spiegelungen Reihe A. Vol. 1. Russen und Rußland aus deutscher Sicht, 9. - 17. Jahrhundert. München, Wilhelm Fink, S. 391-413.

Keuning, J. (1954). Nicolaas Witsen as a Cartographer. In Imago Mundi. Vol. 11, pp. 95-110.

Kiryushchenko, N. V., Krotov, P. A., Kozlov, S. A. (Eds.). (2008). Materialy ekspeditsii Zh.-N. Delilya v Berezov v 1740 g. Dnevnik T. Kenigsfel'da i perepiska Zh.-N. Delilya [Materials of J. N. Delisle's Expedition to Berezov in 1740. The Diary of T. Kenigsfeld and The Correspondence of J. N. Delisle]. St Petersburg, Istoricheskaya illyustratsiya. 544 p.

Kopanev, N. A. (1998). "Tabula rasa" G. V. Leibnitsa [G. V. Leibniz's Tabula Rasa]. In Kopaneva, N. P. (Ed.). G. V. Leibnits i Rossiya. Iz istorii Peterburgskoi akademii nauk. St Petersburg, Evropeiskii dom, pp. 35-40.

Küntzel-Witt, K. (2010). Wie groß ist Sibirien? Die russischen Entdeckungen im Pazifik und die Kontroverse zwischen Joseph Nicolas Delisle, Samuel Engel und Gerhard Friedrich Müller im 18. Jahrhundert. In Happel, J., von Werdt, Ch. (Hrsg.). Osteuropa kartiert - Mapping Eastern Europe. Unter Mitarbeit von Mira Jovanović. Berlin, Zürich, Lit, S. $155-172$. 
Lagarde, L. (1989). Le Passage du Nord-Ouest et la Mer de l'Ouest dans la Cartographie français du $18^{\mathrm{e}}$ Siècle, Contribution à l'Etude de l'Oeuvre des Delisle et Buache. In Imago Mundi. Vol. 41, pp. 19-43.

Leibniz, G. W. (1979). Novissima Sinica (1697). Das Neueste von China / Hrsg. von H. G. Nesselrath, H. Reinbothe. Köln, Deutsche China-Gesellschaft. XIII + 159 S.

Leibniz, G. W. (2006). Der Briefwechsel mit den Jesuiten in China (1689-1714). Französisch/lateinisch/deutsch / Hrsg. und mit einer Einleitung versehen V. R. Widmaier ; Textherstellung und Übersetzung V. M.-L. Babin. Hamburg, Felix Meiner. CXXXVII + 894 S. (Ser. Philosophische Bibliothek. Vol. 548).

Leibniz, G. W. (1923). Sämtliche Schriften und Briefe. Berlin, Deutsche Akademie der Wissenschaften. Darmstadt : O. Reichl.

Les Français en Russie au siècle des Lumières : Dictionnaire des Français, Suisses, Wallons et autres francophones en Russie de Pierre le Grand à Paul Ier : en 2 volumes / sous la direction de A. Mezin, V. Rjéoutski. (2011). Ferney-Voltaire, Centre International d'Étude du XVIIIe siècle. 1424 p.

Li, W., Poser, H. (Hrsg.). (2000). Das Neueste über China. G. W. Leibnizens Novissima Sinica von 1697 : Intern. Symp., Berlin, 4. bis 7 Oktober 1997. Stuttgart, Franz Steiner. 390 S. (Studia Leibnitiana. Supplementa. Vol. 33).

Luckscheiter, S. (2012). Auskünfte für und von Leibniz über Zar Peter I. und die große russische Gesandtschaft (1697-1698). In Li, W. (Hrsg.). Komma und Kathedrale : Tradition, Bedeutung und Herausforderung der Leibniz-Edition : Intern. Konf. in Hannover, 2011. Berlin, Akademie Verlag, S. 293-300.

Maier, L. (2001). Das Sibirienbild in den deutschsprachigen Werken Gerhard Friedrich Müllers. In Baranov, N. N. (Hrsg.). Deutsche auf dem Ural und in Sibirien (XVI-XX Jh.) Forschungsbeiträge der wissenschaftlichen Konferenz "Deutschland-Russland: historische Erfahrungen interregionaler Zusammenarbeit im XVI.-XX. Jahrhundert». Ekaterinburg, Volot, S. 20-54.

Mezin, S. A. (2011). Petr I, Leibnits i Speranskii [Peter I, Leibniz, and Speransky]. In Rossiiskaya istoriya. No. 1, pp. 115-120.

Nevskaya, N. I. (1998). G. V. Leibnits i Peterburgskaya akademiya nauk v XVIII v. [G. V. Leibniz and the Petersburg Academy of Sciences in the $18^{\text {th }}$ Century]. In Kopaneva, N. P. (Ed.). G. V. Leibnits i Rossiya. Iz istorii Peterburgskoi akademii nauk. St Petersburg, Evropeiskii dom, pp. 15-27.

Nitschke, P. (2015). Die Leibnizsche Vision von Europa. In Nitschke, P. (Hrsg.). Gottfried W. Leibniz: Die richtige Ordnung des Staates. Baden-Baden : Nomos. (Staatsverständnisse. Vol. 72). S. 91-111.

Pedley Sponberg, M. (1992). Bel et Utile : The Work of the Robert De Vaugondy Family of Mapmakers. Exeter, Map Collector Publications, S. n.

Piel, G., Luber, S. (1999). Ein "berühmtes Pyrmonter Brunnenjahr" : Zar Peter I in Pyrmont im Juni 1716. In Alfter, D. (Hrsg.). Zar Peter der Große : Die zweite große Reise nach Westeuropa 1716-1717. Hameln, Niemeyer, S. 87-96.

Poser, H. (2013). Leibniz' Novissima Sinica as a Program for the Reunification of the Christian Confessions. In Li, W., Poser, H., Rudolph, H. (Hrsg.). Leibniz und die Ökumene. Stuttgart, Franz Steiner. (Studia Leibnitiana. Sonderhefte. Vol. 41). S. 75-86.

Poser, H. (2016). Leibniz' Philosophie : Über die Einheit von Metaphysik und Wissenschaft / Hrsg. von W. Li. Hamburg, Felix Meiner. 528 S.

Roll, Ch. (2015). Barbaren? „Tabula rasa“"? Wie Leibniz sein neues Wissen über Russland auf den Begriff brachte. Eine Studie über die Bedeutung der Vernetzung gelehrter Korrespondenzen für die Ermöglichung aufgeklärter Diskurse. In Beiderbeck, V. F., Dingel, I., Li, W. (Hrsg.). Umwelt und Weltgestaltung : Leibniz' politisches Denken in seiner Zeit. Göttingen, Vandenhoeck \& Ruprecht. (Veröffentlichungen des Instituts für Europäische Geschichte Mainz. Beiheft 105). S. 307-358.

Schippan, M. (2012). Die Aufklärung in Russland im 18. Jahrhundert. Wiesbaden, Harrassowitz. 493 S. (Wolfenbütteler Forschungen. Vol. 131). 
Schippan, M. (2013). Der „Solon Russlands“ und der Zar. Gottfried Wilhelm Leibniz, Peter der Große und die europäischen Wissenschaftsbeziehungen. In Heinecke, B., Kästner, I. (Hrsg.). Gottfried Wilhelm Leibniz (1646-1716) und die gelehrte Welt Europas um 1700. Aachen, Shaker. (Europäische Wissenschaftsbeziehungen. Vol. 6). P. 133-154.

Shaw, D. J. B. (1996). Geographical Practice and its Significance in Peter the Great's Russia. In Journal of Historical Geography. Vol. 22, pp. 160-176.

Verdier, N. (2015). Des Cartes en situation d'intercertitude : La controverse sur le Kamtchatka entre 1737 et 1738 comme révélateur d'une crise de la cartographie française. In Karp, S. Ya. (Ed.), Kosmolinskaya, G. A. (Comp.). Vek Poscveshcheniya. Iss. 5. Geografiya epokhi Prosveshcheniya: mezhdu voobrazheniem i real'nost'yu. Moscow, Nauka, pp. 100-120.

Witsen, N. Tartaryen: Behelende Eene Beschryving van verscheidene Tartersche en Nabuurige Gewesten, in de Noorder en Oostelykste Deelen van Azien en Europa... Te Amsterdam 1785; 2. Teil: Noord en Oost Tartarye; Tweede Deel: Behelzende de Landschappen Georgia, Mengrelia, Cirkassia, Crim, Astakkia, Altin, Tingoesia, Siberia, en Samojedia door Nicolaes Witsen. Amsterdam 1785 ( $3^{\text {rd }}$ edition, the first shorter edition is from 1692).

The article was submitted on 22.11.2017 